\title{
Marta Cerezo Moreno and Nieves Pascual Soler (eds.) (2016). Traces of Aging. Old Age and Memory in Contemporary Narrative. Bielefeld: Transcript Verlag, 191 pp. ISBN 978 3837634396 (paperback)
}

\author{
REVIEWED by RAQUEL MEDINA*
}

Traces of Aging: Old Age and Memory in Contemporary Narrative is the first comprehensive approach to literary and filmic texts from Paul Ricouer's concept of narrative identity, which is the key concept and common thread connecting the eight essays contributing to this volume. Against the popular perception and representation of aging and old age as decline or as a narrative foreclosure, the eight essays explore fiction as a space in which life can be created and therefore the fear of death diluted if not completely abolished. The editors of the volume, Marta Cerezo Moreno and Nieves Pascual Soler, explain that the essays of this volume encompass a notion of "the function memory processes, of recollection and forgetting, of the retracing of the past" (p. 11). In addition, the eight contributions to the volume conceive old age as "the decisive moment of narrative identity" (p. 12), propose new approaches to the experience of later life, and confirm Ricouer's belief in the ethics of reading; that is, narrative as place of moral judgment. Only by communicating to the other the positive experience of

\footnotetext{
* Raquel Medina, School of Languages and Social Sciences, Aston University, Birmingham, UK
} 
International Journal of Ageing and Later Life

fully embracing growing old can the fear of aging and the discourses of aging as decline be eradicated.

The eight essays included in this volume explore Ricouer's important ideas and notions about aging and death in a wide array of literary texts written by three Canadian authors (Margaret Atwood, Alice Munro, and Saul Bellow), two British (Doris Lessing and Daphne du Maurier), one American (John Barth), and one German (W.G. Sebald). These literary texts are complemented with an essay on a Canadian film from 2013, Still Mine, written and directed by Michael McGowan. The balance regarding the gender of the authors under study is opportune and appreciated, as it demonstrates the important contribution that women writers have made to the discussion of aging and old age. For instance, Simone de Beauvoir, a contemporary to some of the female writers included in the volume, explicitly detailed in The Coming of Age (1972) the social discrimination suffered by women after menopause.

Paul Ricoeur considered that the reality of the historical past subsists in the "traces" left in testimonies, documents, and in the memories of individuals. The trace is the persistence of the past through its remnants in the present. MacDonald's essay on W.G. Sebalds' Austerlitz (2001) illustrates the persistence of the remembered past in the present and the future through its traces. Drawing on Ricouer's concept of living traces, the author describes Austerlitz's rebirth as the encounter with traces that bring the past back to life. Austerlitz travels back to his past by visiting sites that become places of memory. Through his journey back in time, he is able to recount his experiences and reflections to the narrator, thus overcoming the idea of demise usually attached to old age. Teresa Gibert's enlightening essay analyzes Atwood's The Blind Assassin from Ricouer's idea that it is through narration that memory can shape identity. The protagonist's continuous comments about her forthcoming death, as well as her constant forgetting, drive her to revisit the past through the writing of her memoirs. This process underscores the multiple identities taking part in the writing process: her remembering self and her remembered selves.

Ricouer's concept of "points of anchorage" constitutes MiquelBaldellou's point of departure to explore Daphne du Maurier's short story Don't Look Now in which her concealed homosexuality becomes one of the driving forces behind the plot. In fact, Miquel-Baldellou argues that 
it is through the writing process of the short story that du Maurier comes to terms with her sexual identity. Rahel Rivera Godoy-Benesh examines the stories of Tim Manning (The Development 2008), an older character experiencing early symptoms of Alzheimer's disease. This essay aims to demonstrate Ricouer's ideas about narrative identity clash with the fixed conventions of autobiography by focusing on two key concepts: aging and agency within autobiography. The merit of this essay is twofold. On the one hand, it cogently explains the mentioned clash between Ricouer's ideas on identity narratives and the convention of autobiography. On the other hand, and more importantly, it sheds light on the negative impact that the current boom of old age autobiographies may have on perceptions and experiences of old age. That is, the separation of old age into the third and fourth ages (Laslett 1989), where the third age includes those still mentally capable of narrating their self and the fourth age describes those whose ailments impede them from narrating their identity and who can only wait for their death. Life-writing is also the main topic of essay on Doris Lessing's fictional narratives by Angeles de la Concha. The author states that Lessing's autobiographical novels are the best media to examine Ricouer's notion of narrative identity and explore the concept of "happy dreams" that in the British fictional autobiographies defies the cultural discourse of aging as decline.

The only essay in the book devoted to film stands out as the best approach to Ricouer's concept of the grace of insouciance. Pamela Gravagne's analysis of the Canadian film Still Mine (2013) establishes an in-depth dialogue with the ambivalent stance taken by Ricouer: the immediacy of his death does not preclude him from feeling alive. Similarly, this essay establishes the parallels between the narrative deployed in the film and Ricouer's ideas about the new non-chronological temporality that emerge from the narrative.

If confronting the reality of the loved one's forgetting due to dementia is at the center of Still Mine, dementia narrative is key to Alice Munro's The Bear Came Over the Mountain as it is studied by Sara Strauss. In her essay, Strauss approaches the analysis of Munro's acclaimed short story from the idea that Grant creates a narrative identity when telling the story of his wife's dementia while reflecting on his own past. This does not only shape his identity but elicits an ethical response from the reader. 
"Trauma and Postmodern Parody in Saul Bellow's Henderson the Rain King (1959)" is an essay by Collado-Rodríguez which defines this novel as postmodernist, and it deconstructs the way it parodies modernist frameworks such as psychoanalysis and the excessive use of symbols. Using narratology as the methodological framework - the story as the narrative content, the narrative or the text itself, and the narrating process produce narrative action (Genette 1980) - the author elaborates the extreme references to traumatic events, the links between horror mortis and the belief in the mythic cycles of nature. Although it is important to acknowledge the complexity of the topics discussed by Collado-Rodríguez, it is necessary to point out that Ricouer's ideas are absent from the essay.

To conclude, Traces of Aging. Old Age and Memory in Contemporary Narrative proposes an alternative and original approach to the topics of aging and later life in cultural texts. The readings and analyses that constitute the volume offer a unique dialogue with Paul Ricouer's crucial ideas about history, memory, forgetting, the power of traces, and the experience of later life. This volume makes a significant contribution to the field of aging studies and constitutes an important reference point for future studies.

\section{References}

Cerezo Moreno, M. and Pascual Soler, N. (2016). Introduction. in Traces of Aging. Old Age and Memory in Contemporary Narrative. M/ Cerezo Moreno, M. and N. Pascual Soler (eds.). Bielefeld: Transcript Verlag, pp. 7-19.

De Beauvoir, S. 1972. The Coming of Age. Translated by P. O'Brien. New York: Putnam's.

Genette, G. (1980). Narrative Discourse. Ithaca, NY: Cornell University Press. Laslett, P. 1989. A Fresh Map of Life: The Emergence of the Third Age. London: Weidenfeld and Nicolson. 